\title{
Energy and environmental analysis of a rapeseed biorefinery conversion process
}

\author{
Boldrin, Alessio; Balzan, Alberto; Astrup, Thomas Fruergaard
}

Published in:

Biomass Conversion and Biorefinery

Link to article, DOI:

10.1007/s13399-013-0071-9

Publication date:

2013

Document Version

Peer reviewed version

Link back to DTU Orbit

Citation (APA):

Boldrin, A., Balzan, A., \& Astrup, T. F. (2013). Energy and environmental analysis of a rapeseed biorefinery conversion process. Biomass Conversion and Biorefinery, 3(2), 127-141. https://doi.org/10.1007/s13399-0130071-9

\section{General rights}

Copyright and moral rights for the publications made accessible in the public portal are retained by the authors and/or other copyright owners and it is a condition of accessing publications that users recognise and abide by the legal requirements associated with these rights.

- Users may download and print one copy of any publication from the public portal for the purpose of private study or research.

- You may not further distribute the material or use it for any profit-making activity or commercial gain

- You may freely distribute the URL identifying the publication in the public portal

If you believe that this document breaches copyright please contact us providing details, and we will remove access to the work immediately and investigate your claim 
Accepted for publication in Biomass Conversion and Biorefinery

\title{
Energy and environmental analysis of a rapeseed biorefinery conversion process
}

\author{
Alessio Boldrin, Alberto Balzan, and Thomas Astrup \\ Department of Environmental Engineering \\ Technical University of Denmark \\ Kgs. Lyngby, Denmark
}

"NOTE: this is the author's version of a work that was accepted for publication in Biomass Conversion and Biorefinery journal. Changes resulting from the publishing process, such as peer review, editing, corrections, structural formatting, and other quality control mechanisms may not be reflected in this document. Minor changes may have been made to this manuscript since it was accepted for publication. A definitive version is published in Biomass Conversion and Biorefinery, vol 3, pp 127-141, doi: 10.1007/s13399-013-0071-9" 


\begin{abstract}
The need for biofuels is steadily increasing as a result of political strategies and the need for energy security. Biorefineries have the potential to improve the sustainability of biofuels through further recovery of valuable bioproducts and bioenergy. A life cycle assessment (LCA) based environmental assessment of a Danish biorefinery system was carried out to thoroughly analyze and optimize the concept and address future research. The LCA study was based on case-specific mass and energy balances and inventory data, and was conducted using consequential LCA approach to take into account market mechanisms determining the fate of products, lost opportunities and marginal productions. The results show that introduction of enzymatic transesterification and improved oil extraction procedure result in environmental benefits compared to a traditional process. Utilization of rapeseed straw seems to have positive effects on the greenhouse gases (GHG) footprint of the biorefinery system, with improvements in the range of 9 to $29 \%$, depending on the considered alternative. The mass and energy balances showed the potential for improvement of straw treatment processes (hydrothermal pre-treatment and dark fermentation) as well as minor issues related to enzymes utilization in different bio-processes.
\end{abstract}

Keywords: rapeseed, biofuel, biorefinery, LCA, enzymes. 


\section{Introduction}

Demand for biofuels has been steadily increasing in the last years as a result of a growing need for economically viable energy security on one hand and on the other hand of legislative mandates aiming to prompt Kyoto oriented GHG control measures. For instance, the European Union has adopted in 2009 the Renewable Energy Directive, endorsing a mandatory $10 \%$ minimum target for the share of energy from renewable sources in transportation by 2020 [1]. This resolution is foreseen to boost the production of liquid biofuels in the coming years with global consequences related to the competition between energy crops and food crops [2]. To regulate these effects, the directive sets sustainability criteria for the biofuels - calculated on thorough LCA-type analyses, addressing the development of improved productions schemes and promotes the production of $2^{\text {nd }}$ generation fuels in order to better exploit also residual biomass resources [1].

Biodiesel is the most important biofuel in Europe, representing about $80 \%$ of the biofuels sector [3]. Biodiesel has been produced from different oil crops (e.g. rapeseeds, palm fruits, soya seeds, sunflower seeds) for many years, rapeseed being the main feedstock and covering about $80 \%$ of the biodiesel production in the EU [3]. Technological improvements are constantly introduced in processing schemes and the plants with larger scale are built or planned. However, first generation rapeseed-based biodiesel is not considered a very effective production route, because the recoverable oilseed represents less than $1 / 3$ of the biomass obtained in the field [4]. To improve the environmental footprint of biodiesel production, a $2^{\text {nd }}$ generation biorefinery approach using the whole crop was suggested to co-produce bioenergy, biochemicals and biomaterials and thus overall increase the efficiency of rapeseed utilization [5]. The potential benefits of further utilizing rapeseed by-products were suggested in several studies [e.g. 6-8] and could represent an instrument for meeting the above mentioned sustainability criteria set by EU [9].

LCA studies on biorefinery systems are scarcely reported in literature, especially studies including specific data and modelling of straw utilization for recovery of extra valuables [5]. An almost common feature of these studies is that the cause-effect chain induced by market mechanisms on the trading of products is only partially modelled. In the near future, biomass 
will be a constrained resource/commodity, and such a constraint will determine market competition between different actors and need for alternative supply routes. These market related consequences have to be modelled in an LCA study if the study is to be used for consistent decision making [10]. Furthermore, most of the LCAs on biorefineries have a general character and they make use of default data, thereby focusing more on how biorefineries integrate in the energy system rather than on the technology development [e.g. 61, 62]. As a consequence, detailed studies of (specific) upcoming or future technologies are almost nonexisting. For instance, in their analysis Harding et al. [11] showed the environmental benefit of using enzymatic transesterification over inorganic catalysis, but its relevance at a biorefinery system level was not analysed.

The objective of the study is to provide a detailed analysis of a biorefinery concept under development in Denmark. This is done by 1) establishing detailed mass and energy balances; 2) collecting specific inventory data; 3) carrying out a consequential LCA to compare different configuration of the biorefinery process; and 4) performing sensitivity analysis to strengthen the conclusions. The aims of the assessment are to optimize the utilization of rapeseed and the operation of the biorefinery system - thus focusing on $1 \mathrm{Mg}$ of rapeseed (upstream processes are not included) - and to address whether and where research-based improvements of the process are possible from an environmental perspective.

\section{Goal and scope definition}

\subsection{Methodology}

The study followed consequential LCA approach and aimed at defining more effective and sustainable processing methods for $1 \mathrm{Mg}$ of rapeseed harvested in Denmark. The individual processes and technologies analysed are currently in operation at pilot or industrial scale, while their combination into integrated schemes is still under development [13]. Large industrial biorefineries are expected to be fully operative within 5-10 years [13].

Material Flow Analysis (MFA) and energy balance was performed by means of the massbalance model STAN version 2.0 [32]. The LCA modelling was facilitated with the LCA-tool SimaPro [33], partly based on the ECOINVENT 2.2 database, unless otherwise stated. 
In all the analysed scenarios, different products are delivered to the market, thereby displacing the production of equivalent alternatives elsewhere in the system (assuming the products are economically competitive). Following standard practice within LCA, system expansion was performed to include benefits/burdens related to these replacements/substitutions on the market (see section 2.6 for details). Potential environmental impact categories under investigation were Global Warming, Acidification and Terrestrial Eutrophication. Impact assessment was carried out based on the EDIP2003 method [34] for a time horizon of 100 years. The results are calculated as characterised potential environmental impacts and presented both as aggregated and disaggregated values. The disaggregated results are presented in two versions, i.e. according to process contribution and to product contributions. While still including benefits/burdens of the substituted products, the disaggregated results are calculated using energy allocation to distribute upstream impacts to the outputs of the individual sub-process of the biorefinery.

\subsection{The biorefinery system: a description}

The biorefinery system is schematically presented in Figure 1. The biorefinery includes processing of both seeds and straw from rapeseed for integrated production of biodiesel, bioethanol, biogas, biohydrogen. Properly handled, some of the by-products can be exploited for additional energy recovery (e.g. glycerine and lignin) or marketed in substitution of industrially manufactured products (e.g. glycerine and digestate). During harvesting, rapeseed is mechanically sorted (separated) into rape seeds and straw. Rapeoil is extracted from oilseeds by means of combined mechanical and enzymatic (for the hulls) treatment; press cake is obtained as by-product from the process. The conversion of rapeoil to Rape Methyl Ester (RME), one form of biodiesel, is performed through enzymatic transesterification, in which a mixture of rendered oils and virgin rapeseed oil react with methanol (produced by a catalytic methane reforming process, potentially part of the biorefinery scheme) in a solvent-free carbon membrane reactor (CMR) with immobilised enzymes - Thermomyces laguginosa (Lypozyme TL) mixed with Candida antartica (Novozym 435) - as catalysers [12-13]. Glycerine, which is a byproduct from the reaction, can be used for a range of purposes as raw material for different industrial processes, in industrial boilers for energy production, and/or processed in a digester 
for biogas production. The press cake is further processed in the biorefinery by means of supercritical fluid extraction ( $\mathrm{CO}_{2}$ as a solvent) to recover glucosinolates and glucosinolate derived compounds [14]. This operation serves two purposes. On one hand the quality of rape meal (the processed rape cake) is improved by removing substances which are potentially toxic for animals at high doses and by increasing the availability of proteins in the meal. On the other hand, valuable products - such as food and plant protection agents and health care compounds- can be produced from glucosinolates [15-16]. However, both the extraction of glucosinolate and its possible uses are still under research and detailed information was not found in literature. Accordingly, both extraction and potential downstream utilization of glucosinulates have not been included in the present modelling.

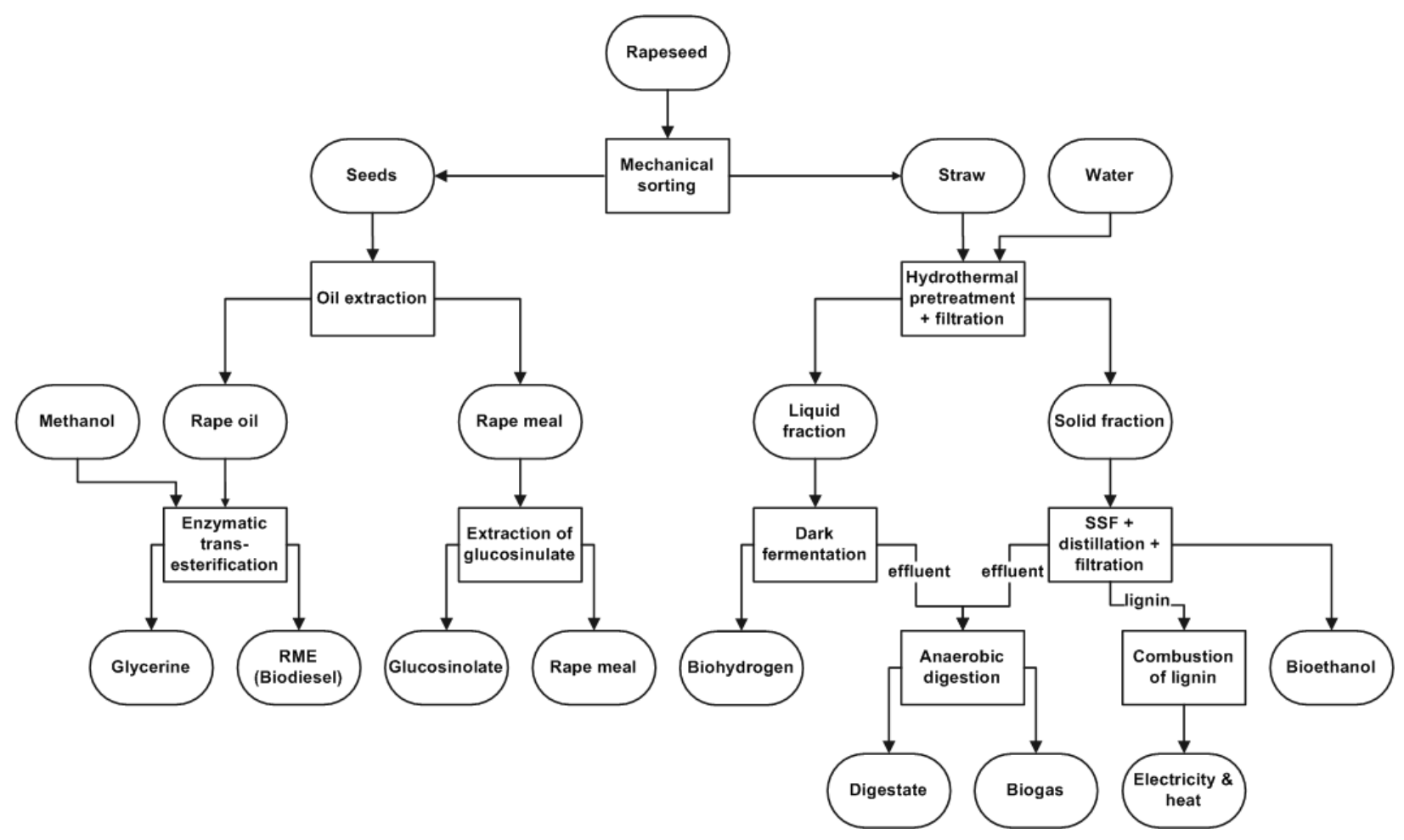

Figure 1 - Biorefinery system outline (Scenario 4).

The collected rape straw is a lignocellulosic material and consists of three main fractions: 1$)$ cellulose ( $C_{6}$ glucose polymers), 2 ) hemicelluloses ( $C_{5}$ sugar polymers), and 3 ) lignin. Cellulose can be converted after further processing to ethanol, while hemicellulose can be used as raw material for hydrogen production. The straw is pretreated by means of the 
Liquid Hot Water (LHW) method, followed by filtration to separate a liquid fraction (hydrolysate) rich in hemicellulose (pentose sugars: xylose and arabinose) and a solid fraction containing cellulose (hexose sugars: glucose), lignin, ash and the undissolved hemicellulose [1719]. The hydrolysate is utilized for biohydrogen production through extreme thermophilic dark fermentation using basic anaerobic (BA) medium as inoculum [20]. The solid fraction is used for bioethanol production in a Simultaneous Saccharification and Fermentation (SSF) bioreactor equipped with a direct vacuum distillation unit [21]. The process makes use of Celluclast 1,5L. and b-glycosidase (Novozym 188) for the enzymatic hydrolysis and Saccharomyces cerevisiae as fermenting microorganisms. The lignin is not affected during the fermentation process [22] and is recovered from the residual stillage by means of filtration. The lignin is subsequently combusted for recovery of energy. The remaining liquid fraction of the stillage is collected together with the effluent from the dark fermentation reactor (biohydrogen production) and co-digested in a thermophilic $\left(55^{\circ}\right)$ anaerobic reactor for production of biogas.

\subsection{The biorefinery system: mass balance}

Figure 2 presents the Total Solids (TS) balance of the biorefinery system. Assuming a straw-tocrop ratio of 0.9 on dry basis [55], $1 \mathrm{Mg}$ wet weight (ww) of whole rapeseed delivered at the gate of the biorefinery consists of $538 \mathrm{~kg}_{\mathrm{ww}}$ of seeds and $462 \mathrm{~kg}_{\mathrm{ww}}$ of straw. This corresponds to $490 \mathrm{~kg}$ dry weight (dw) of seeds and $441 \mathrm{~kg}_{\mathrm{dw}}$ of straw, assuming TS contents of 91\% [23] and 95.4\% [25] respectively.

Data regarding rapeoil extraction by enzymatic hydrolisation of the biomass were not available in literature. As a conservative estimate, we have assumed that this process has a similar performance as a state-of-the-art solvent extraction method, i.e. a meal-to-oil ratio of 1.38 on wet basis [23] was used. This assumption was based on the fact that the enzymatic method was reported enhancing oil extractability up to 10\% [24] compared to the full press technology, which has a meal-to-oil ratio around 1.50-1.58 [6, 23, 26, 27]. The resulting flows were thus $216 \mathrm{~kg}_{\mathrm{dm}}$ of rapeoil and $273 \mathrm{~kg}_{\mathrm{dm}}$ of rape meal. 


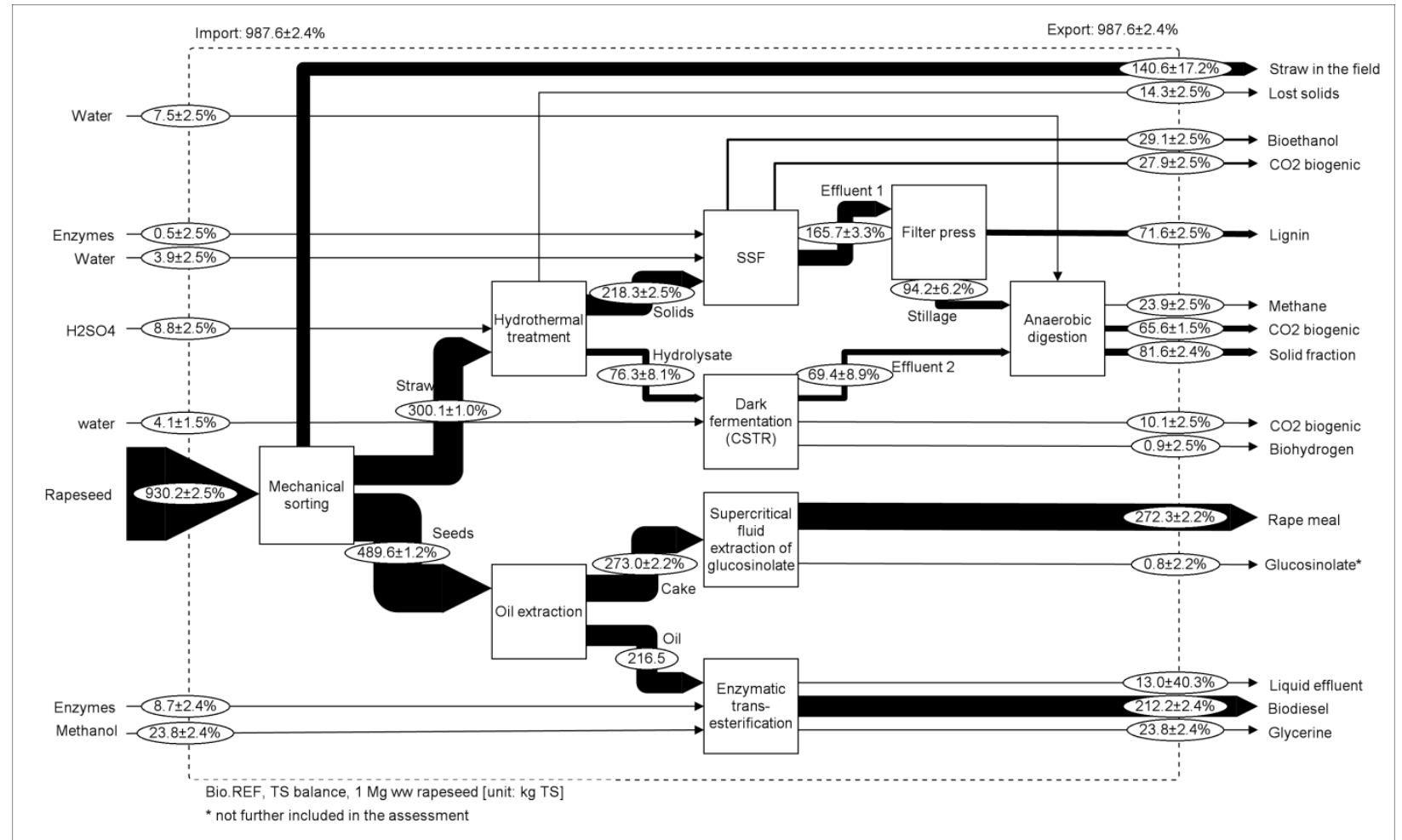

Figure 2 - Biorefinery mass balance (Scenario 4) for $1 \mathrm{Mg} w \mathrm{w}$ input of rapeseed. Values are expressed in $\mathrm{kg}$ TS.

The amount of RME and glycerine obtained from rapeoil depend on the chemical composition of the rapeoil used and thus different data can be found in literature. Based on data from Thyø et al. [4], Halleux et al. [6], and Jungbluth [26], we have assumed average data according to the following Equation 1, where the variation interval represents the data range found in the literature:

\begin{tabular}{|c|c|c|c|c|}
\hline rapeoil & methanol & RME & glycerine & (Equation 1) \\
\hline $1000 \mathrm{~kg}]$ & {$[110 \pm 3 \mathrm{~kg}]$} & {$[980 \pm 20 \mathrm{~kg}]$} & {$[110 \pm 10 \mathrm{~kg}]$} & \\
\hline
\end{tabular}

This relationship does not take into account for possible surplus of methanol added to the process, both because this surplus is very limited and because methanol is recovered from the glycerine and recirculated back to the biodiesel reactor. The process is supposedly catalyst- and solvent-free, thus no other materials (e.g. catalysts such as $\mathrm{KOH}, \mathrm{NaOH}$; or catalyst breaker such as $\mathrm{H}_{3} \mathrm{PO}_{4}$; or solvent such as $n$-hexane, tert-butanol) are included. A small amount of ammonium hydroxide used to neutralize remaining free fatty acids was included in the 
inventory but not shown for simplicity in the mass balance (Figure 2). The load of enzymes in the reactor was 3\% Lipozyme TL IM and 1\% Novozym 435 [12-13] based on rapeoil weight. The enzyme productivity was estimated to $1200 \mathrm{~kg}$ biodiesel $\mathrm{kg}^{-1}$ enzyme [28], corresponding to an enzyme consumption of $0.82 \mathrm{~kg}$ per $\mathrm{Mg}$ rapeoil. A conservative assumption of $2.00 \mathrm{~kg}$ per $\mathrm{Mg}$ rapeoil was used (1.5 kg Lipozyme TL IM and $0.5 \mathrm{~kg}$ Novozym 435). Liquid effluents consisting of free fatty acids, methyl esters and spent enzymes were assumed treated in municipal wastewater treatment plants [26].

The content of glucosinolate in the rape meal was in the order of $10.6 \mathrm{mmol} \mathrm{kg}^{-1} \mathrm{dw}_{\text {[29]. }}$ Assuming a recovery efficiency of $50 \%$ for the supercritical fluid extraction method and a molar weight of $455 \mathrm{~g} \mathrm{~mol}^{-1}$ (this may vary between $415-495 \mathrm{~g} \mathrm{~mol}^{-1}$ [64]), we estimated a recovery of $0.67 \mathrm{~kg}$ of glucosinolate compounds from the total amount of rape meal.

It was assumed that $65 \%$ (i.e. the maximum harvestable [30]) of the straw was collected from the fields, corresponding to $286 \mathrm{~kg}_{\mathrm{dw}}$ of straw delivered to the biorefinery for processing and $154 \mathrm{~kg}_{\mathrm{dw}}$ left on the field. The collection of straw was modelled based on the ecoinvent process "Baling/CH S" [30]. The environmental effects of straw removal are reduction soil organic carbon (SOC) content, removal of $\mathrm{N}, \mathrm{P}, \mathrm{K}$ nutrients and change in $\mathrm{N}_{2} \mathrm{O}$ emission pattern $[59,60]$. A decrease in SOC of $0.31 \mathrm{Mg} \mathrm{C} \mathrm{ha}^{-1} \mathrm{yr}^{-1}$ was calculated according to the IPCC [65] (country: Denmark; climate region: cold temperate, moist; native soil type: high clay activity mineral; land use type: long-term cultivated, full-tillage, from medium to low input). It should be noted that decrease in SOC may affect the crop yield. This effect was however not included, because a link between SOC and crop yield cannot be accurately quantified, being crop yield also determined by other concurring factors [57]. Removal of N, P, K nutrients with the straw implies additional application of mineral fertilizers to keep the yield constant. The amount of inorganic fertilizers was 6.5 and $1.1 \mathrm{~kg}$ of $\mathrm{N}, \mathrm{P}$ respectively per $\mathrm{Mg}_{\mathrm{dw}}$ straw [56], while a value of $2.8 \mathrm{~kg}$ of $\mathrm{K}$ per $\mathrm{Mg}_{\mathrm{dw}}$ straw was taken from Cherubini \& Ulgiati [8], considering wheat straw a reasonable estimation for rape straw. Decreased $\mathrm{N}_{2} \mathrm{O}$ emission in the order of $0.03 \mathrm{Kg} \mathrm{N}-\mathrm{N}_{2} \mathrm{O}$ $\mathrm{Mg}^{-1}{ }_{\mathrm{dw}}$ (or $0.047 \mathrm{Kg} \mathrm{N}_{2} \mathrm{O} \mathrm{Mg}_{\mathrm{dw}}^{-1}$ ) were modelled according to the assumption made by Cherubini \& Ulgiati [8], which is based on estimations by Gabrielle \& Gagnaire [54]. 
Hydrothermal pretreatment of the collected straw was assumed to have an optimized performance reported by Lu et al. [31]: $56.9 \%$ of the cellulose and $68.4 \%$ of the hemicellulose contained in the raw straw were recovered in the solid fraction (to SSF for bioethanol production) and hydrolysate (to dark fermentation) by operating the process with $1 \% \mathrm{w} / \mathrm{w}$ sulphuric acid $\left(\mathrm{H}_{2} \mathrm{SO}_{4}\right)$ and $20 \%$ solid content for $10 \mathrm{~min}$ at $180^{\circ} \mathrm{C}$. It was calculated that the $20 \%$ solid content is obtained by adding about $3.8 \mathrm{~L} \mathrm{~kg}^{-1} \mathrm{TS}$ input (705 kg in total with $176 \mathrm{~kg}_{\mathrm{dm}}$ input). During pretreatment, $5 \%$ of the solids (proportionally distributed among components) are lost [21]. The remaining fractions of cellulose and hemicellulose were assumed to be in the solid fraction - together with the lignin - but not available for fermentation. No water needed to be added to the SSF and dark fermentation processes, as the amount of water added during the hydrothermal pretreatment was enough to sustain these processes [21].

The SSF process requires input of enzymes for the hydrolysis of cellulose. The load of enzymes was $0.11 \mathrm{~g} \mathrm{~g}^{-1}$ cellulose and $0.05 \mathrm{~g} \mathrm{~g}^{-1}$ cellulose for $24 \mathrm{~h} \mathrm{[31]} \mathrm{for} \mathrm{celluclast} 1.5 \mathrm{~L}$ and Novozym188 respectively. Similarly to the transesterification process, enzyme load was estimated to $5 \%$, meaning that a consumption of $5.5 \mathrm{~g}$ and $2.5 \mathrm{~g} \mathrm{~kg}^{-1}$ cellulose of Celluclast $1.5 \mathrm{~L}$ and Novozym 188 respectively was assumed. Bioethanol was produced from hydrolysed cellulose according to the following Equation 2:

$$
\mathrm{C}_{6} \mathrm{H}_{12} \mathrm{O}_{6} \rightarrow 2 \mathrm{CH}_{3} \mathrm{CH}_{2} \mathrm{OH}+2 \mathrm{CO}_{2} \quad \text { (Equation 2) }
$$

The efficiency of the process is assumed to be $90 \%[17,18,21]$, meaning that about $460 \mathrm{~g}$ of ethanol and $440 \mathrm{~g}$ of $\mathrm{CO}_{2}$ are produced per $\mathrm{kg} \mathrm{dm}$ of cellulose. The filtration process of the stillage was assumed to recover $95 \%$ of the lignin and $50 \%$ of the ash into the solid fraction, while the remaining lignin and ash were assumed to remain in the liquid stillage sent to anaerobic digestion, together with non-processed cellulose and non-hydrolysed cellulose and hemicellulose.

Hydrogen is produced during dark fermentation from non-hydrolysed hemicellulose and cellulose according to the following (simplified) reactions (Equation 3 and Equation 4): 
$\mathrm{C}_{5} \mathrm{H}_{10} \mathrm{O}_{5}+1 \frac{2}{3} \mathrm{H}_{2} \mathrm{O} \rightarrow 3 \frac{1}{3} \mathrm{H}_{2}+1 \frac{2}{3} \mathrm{C}_{2} \mathrm{H}_{3} \mathrm{O}_{2}^{-}{ }_{3}+1 \frac{2}{3} \mathrm{H}^{+}+1 \frac{2}{3} \mathrm{CO}_{2}$

$\mathrm{C}_{6} \mathrm{H}_{12} \mathrm{O}_{6}+2 \mathrm{H}_{2} \mathrm{O} \rightarrow 4 \mathrm{H}_{2}+2 \mathrm{C}_{2} \mathrm{H}_{3} \mathrm{O}_{2}^{-}+2 \mathrm{H}^{+}+2 \mathrm{CO}_{2}$

(Equation 4)

The efficiency of the overall process was assumed to be $50 \%$ [20], corresponding to production of $22 \mathrm{~g}$ of $\mathrm{H}_{2}$ and $240 \mathrm{~g}$ of $\mathrm{CO}_{2}$ per $\mathrm{kg} \mathrm{dm}$ of hydrolysate $(95 \%$ pentose and $5 \%$ hexose hydrolysed sugars).

In the anaerobic digestion process, biogas was produced from different substrates recovered from previous processes:

- Hemicellulose and cellulose not hydrolysed during pretreatment and contained in the solid fraction;

- Hemicellulose and cellulose hydrolysed during pretreatment but not utilized during SSF or dark fermentation;

- By-products from the dark fermentation (acetic acid).

The following general reaction (Equation 5) was used to estimate the production of biogas from the above mentioned substrates:

$\mathrm{C}_{n} \mathrm{H}_{a} \mathrm{O}_{b}+\left(n-\frac{a}{4}-\frac{b}{2}\right) \mathrm{H}_{2} \mathrm{O} \rightarrow\left(\frac{n}{2}-\frac{a}{8}-\frac{b}{4}\right) \mathrm{CH}_{4}+\left(\frac{n}{2}-\frac{a}{8}-\frac{b}{4}\right) \mathrm{CO}_{2} \quad$ (Equation 5)

The efficiency of this process was assumed to be $80 \%$, which was within the range suggested by [21]. The non-degraded organic matter was assumed to be transferred to the digestate outflow from the biogas reactor.

\subsection{The biorefinery system: energy balance}

The energy balance for the biorefinery system is presented in Figure 3 (displayed as primary energy, as suggested by Börjesson \& Tufvesson [63]) and includes energy carried by individual material flows and energy inputs/losses to the different processes. The energy contained in different material flows was estimated using the calorific values presented in Table 1 and the 
mass flows shown in Figure 1. Electricity and heat requirements for each process were estimated according to unit process data presented in Table 2 and mass flows shown in Figure 2. Provisions of electricity and heat were modelled using the marginal Danish production, as described later. The primary energy embedded in energy and material inputs was estimated according to factors presented in Table 3. Inventory data for enzyme provision were obtained from producers [66], but the complete inventory is hereby not reported for confidentiality reasons; data regarding primary energy consumption associated to enzyme production is reported in Table 3. No data were available for the enzymatic transesterification process as the technology has not yet been demonstrated and reported at an industrial scale. However, it was assumed that the enzymatic transesterification process uses less energy (fewer treatment steps) and much less water than the traditional process [13]. Thus, in the present study $30 \%$ and $50 \%$ lower energy and water consumption was assumed compared with the traditional catalytic transesterification process, according to calculations by Sotoft et al. [28]. The water consumption during the catalytic transesterification process was assumed to be $26.6 \mathrm{~L} \mathrm{Mg}^{-1}$ rapeoil input [26]. The relevance of this assumption is discussed further in the sensitivity analysis.

Figure 3 shows that biodiesel represented the product carrying the largest energy output (7750 MJ Mg-1 of harvested straw). The energy contained in the harvested straw is on the other hand more evenly distributed across the different outputs (ethanol, lignin, methane and hydrogen) of the biorefinery.

Energy losses include both energy lost through the degradation process (organic matter converted to $\mathrm{CO}_{2}$ and heat) and mechanical energy spent for the processing. Table 2 shows the relevance of energy losses for single processes, expressed as $\mathrm{kJ}$ of energy lost per $\mathrm{MJ}$ of primary energy input (sum of energy contained in the organic flows plus the primary energy embedded in ancillaries) to the processes. 


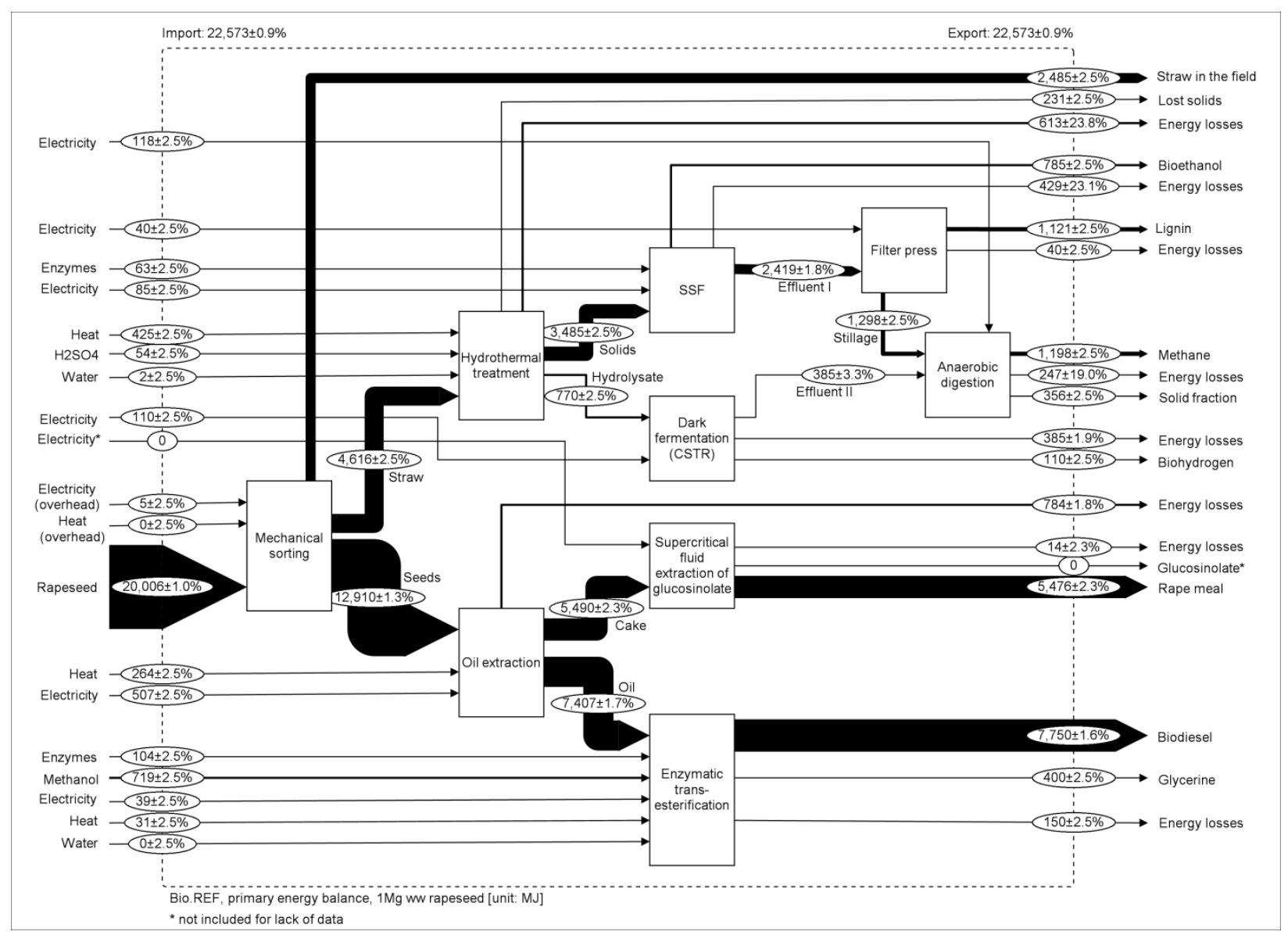

Figure 3 - Biorefinery primary energy balance for $1 \mathrm{Mg} w \mathrm{w}$ input of rapeseed. Values are expressed in MJ.

Energy intensities of the processes were calculated and reported in Table 2. Energy intensity is defined as the amount $(\mathrm{kJ})$ of primary energy used per unit (MJ) of energy input to the processes (energy contained in the rapeseed-related organic flows). According to the results, the most energy intensive processes are enzymatic transesterification, anaerobic digestion and hydrothermal pre-treatment, suggesting that for these processes there is a potential for further technological development and optimization. However, in case of enzymatic transesterification most of the energy input (i.e. methanol) is then recovered in the output (biodiesel), with low energy losses. 


\subsection{LCA scenarios}

The biorefinery system was compared with four alternative scenarios/technologies to assess whether the introduction of technological innovation resulted in environmental benefits and enhanced efficiency for the processing of rapeseed. The following sections present the methodological choices/assumptions within the LCA framework and a brief description of the five compared scenarios, while outlines of the scenarios are provided in the Supplementary Material (Figure S1 to Figure S5). Scenarios were developed based on the reference scenario (S1), representing the traditional biodiesel production from rapeseed. In the following scenarios, innovative technologies/solutions developed in the integrated biorefinery concept are sequentially introduced to test their environmental performance, until Scenario 4, which represents the biorefinery concept above described. Scenario 5 represents an alternative to scenario 4 within the integrated biorefinery concept. A detailed overview of inventory data and process parameters are presented in table 5 . The assessment had a technological focus aiming at thoroughly analysing the conversion processes, comparing different configurations and identifying potential improvements. For the sake of comparison, the provision of rapeseed was thus excluded from the system boundaries, as it would have been the same for all the investigated scenarios.

\subsubsection{Scenario 1 - Traditional rapeseed refinery (S1)}

In Scenario 1, rapeseed is mechanically sorted into rape seeds and straw during harvesting. Straw is left on the field and not utilised further. Rapeoil is extracted from rape seeds by means of full press technology (using hexane as a solvent), with a meal-to-oil ratio of 1.5 [27] per dry basis. Biodiesel is produced in a transesterification process where $\mathrm{NaOH}$ is used as a catalyser for the process. The consumption of $\mathrm{NaOH}$ was assumed to be $1 \%$ based on rapeoil weight [13]. Inventory data for the transesterification process were obtained from the ecoinvent database ("Rape methyl ester, at esterification plant, RER", [26]) and adjusted according to the amounts of rapeseed produced in the Danish system. Consumption of methanol and

productions of glycerine and RME were assumed to be the same for all scenarios, regardless of the employed technology. 


\subsubsection{Scenario 2 - Enzymatic transesterification (S2)}

In Scenario 2, the introductions of improved rapeoil extraction methods and enzymatic transesterification were assessed. Similarly to S1, rapeseed is mechanically sorted into rape seeds and straw during harvesting. Straw is left on the field and not further utilised. Rapeoil is extracted from oilseeds by means of combined mechanical and enzymatic treatment (hulls), assuming a meal-to-oil ratio of 1.32 per dry basis. RME is produced in an enzymatic transesterification process as described for the biorefinery concept.

\subsubsection{Scenario 3 - Straw combustion (S3)}

In Scenario 3, recovery of straw and its utilization for energy purposes was assessed. Rapeseed is treated as in S2 and RME, glycerine and rape meal are the co-products. The amount of straw harvested is $65 \%$ as described for the biorefinery concept. The straw was assumed to be combusted in a straw-fired combined heat \& power (CHP) plant for production of electricity and heat. Straw combustion is today an integrated part of the Danish energy system and about $32 \%$ of all straw produced was used for energy production in 2009 [35]. The net energy recovery efficiency was assumed to be $21.8 \%$ and 59.8 for electricity and heat respectively, as reported for a typical small-scale CHP plant in Denmark [14]. This implies a production of $4.7 \mathrm{GJ}$ of electricity and $12.9 \mathrm{GJ}$ of heat per $\mathrm{Mg}$ of straw (calorific value $=21.5 \mathrm{MJ} \mathrm{kg}^{-1} \mathrm{TS}$, Table 1 ).

\subsubsection{Scenario 4 - Biorefinery (S4)}

In Scenario 4, the biorefinery concept as described in section 2 is assessed. This included the use of straw for the production of bioethanol in SSF process, biohydrogen through dark fermentation and biogas through anaerobic digestion, and generation of electricity from combustion of woody residues from SSF reactor.

\subsubsection{Scenario 5 - Digestion of hydrolysate (S5)}

As an alternative to dark fermentation in Scenario 4, the hydrolysate is routed directly to anaerobic digestion in Scenario 5. The performance of the anaerobic digestion process was 
assumed to be the same as in Scenario 4, as well as energy consumptions per unit of feedstock input.

\subsection{Substituted processes}

Choices and assumption related to substitutions are discussed in the following paragraphs, while an overview of possible substituted processes (also called "lost opportunities") is presented in Table 5.

\subsubsection{Biofuels}

Rape methyl ester (RME) is a fuel comparable to conventional diesel. When low shares of RME are blended to conventional diesel, adjustment of cars' engine is not needed [26]. The substitution is modelled on a 1:1 energy basis, using the ECOINVENT process "Operation, Operation, passenger car, diesel, fleet average" [26] to model the substituted diesel. Emissions of exhaust gases from combustion of RME in a diesel blend were modelled based on data from Pelkmans et al. [58].

Glycerine produced during the transesterification process can have several applications, as shown in Table 5. The upgrading and use of glycerine as raw material in industrial processes would be an environmentally sound choice, as the production of synthetic glycerine requires large inputs of fossil energy [36]. However, with the growing biofuel market the amount of glycerine co-produced with biodiesel is likely to be several times larger than the market capacity [36]. Therefore, the use of glycerine for energy purposes is the most likely consequence in the future. It is here assumed that glycerine is used in gas-fired industrial boilers, as this solution is already technically available [4]. In this case, the displaced fuel is natural gas with an assumed substitution ratio of $1 \mathrm{GJ}$ of glycerine to $0.94 \mathrm{GJ}$ of natural gas [4]. Emissions from combustion of glycerine are assumed to be the same as for natural gas combustion.

Ethanol can be blended with conventional gasoline, substituting fossil gasoline on a 1:1 energy basis. It was assumed that 5 vol.-\% bioethanol is blended with 95 vol.-\% gasoline, as allowed in the European standard for gasoline EN-228. The substitution was modelled using the 
ECOINVENT process “Operation, passenger car, petrol, fleet average 2010" [26] for the substituted gasoline, while data from Pelkmans et al. [58] were used with regards to emissions from combustion of bioethanol in gasoline blends.

Hydrogen produced during dark fermentation may be used for different purposes, as shown in Table 5. It was assumed that hydrogen is upgraded and used in industrial processes, thus replacing hydrogen produced from steam reforming of natural gas. The substitution was modelled on a 1:1 mass basis.

Biogas generated during anaerobic digestion is used for energy production. It is assumed that after a cleaning stage the biogas is combusted in a gas engine, where electricity is generated with an efficiency of $42 \%$ and delivered to the grid. Heat is also co-generated in the engine, but used internally.

\subsubsection{Electricity and heat}

Electricity and heat produced from the biorefinery are delivered to the grid (national for electricity, local for district heating), displacing energy production elsewhere in the system. For Denmark, the marginal technology (i.e. the avoided production) for electricity production was assumed to be coal [37-38]. In case of biogas utilization, an alternative to gas engine could be the combustion of biogas in gas-fired power plants, thus replacing natural gas. However, this substitution mechanism is at all similar to the gas engine, because an increase in electricity generation based on natural gas will push in the long term coal-based energy out of the system, hence making coal the marginal fuel. On the other hand, the production of heat has consequences at a local scale. For Danish conditions, the production of heat from the biorefinery system is most likely to affect heat production at decentralised natural gas fired plants [39-40], which was therefore assumed to be the substituted technology.

\subsubsection{Other outputs}

Glucosinolates extracted from the rape meal can potentially be used for different purposes. As introduced earlier, it is anticipated that they can be used as food and plant protection agents (e.g. biopesticides) or they can be further processed into human medicaments (e.g. anti- 
carcinogenic compounds). However, possible applications are currently under research and sufficient information for definition of downstream processes is not yet available in literature. Thus, the substitution of other products by glucosinolates is not included in the modelling.

Rape meal is used as animal fodder. As described by Schmidt \& Weidema [41], the fodders replaced by the use of rape meal are and barley meals, sources of proteins and energy respectively. Furthermore, the avoided production of soybean meal would result in a decreased supply of soybean oil, which has to be provided by palm oil (i.e. the marginal vegetable oil). This means that $1 \mathrm{Mg}$ of rape meal displaces the production of $979 \mathrm{~kg}$ soybean (or $763 \mathrm{~kg}$ of soybean meal) in Brazil and $114 \mathrm{Kg}$ barley in Canada and induces an increased production of $239 \mathrm{~kg}$ of palm oil fruit in Malaysia (calculated based on Schmidt [23] using a meal-to-oil ratio of 1.38). Inventory data for soybean production in Brazil and barley production in Canada were taken from Schmidt [23], in both cases including intensified production and land expansion. The supercritical fluid extraction employed for recovering glucosinolates in Scenarios 4 and 5 increases the net protein utilization (NPU) value of the rape meal - because the biological value (BV) is increased. It is estimated that the NPU of rape meal can increase from average values of 65-70 up to 80. This increase in NPU thus implies that a larger amount of marginal protein source (soy meal) can be substituted. This was in Scenario 4 and 5 modelled by a $10 \%$ increase in both the amount of soybean displaced and the production of palm oil.

Digestate generated during anaerobic digestion can be used as fertilizer on agricultural land, thus displacing the production of inorganic fertilizer at an industrial level. According to Norouzi et al. [42], rape straw contains $0.83,0.057$ and $0.76 \% \mathrm{TS}$ of $\mathrm{N}, \mathrm{P}$ and $\mathrm{K}$ respectively (values in line with other references such as BIOBIB database and Sander [43]). The fertilizing potential of the digestate has been estimated assuming that $N, P, K$ are not degraded during biological process and that $25.3 \%$ (same as TS) is removed in the filter press together with lignin. Hence, the nutrients recovered in the digestate are $6.2,0.43$ and $5.7 \mathrm{~kg}$ of $\mathrm{N}, \mathrm{P}$ and $\mathrm{K}$ respectively per tonne dw of straw or $28.7,2.0$ and $26.4 \mathrm{~kg}$ of $\mathrm{N}, \mathrm{P}, \mathrm{K}$ per tonne dw of digestate. The utilization rates for the nutrients are assumed to be $40,100,100 \%$ for N,P,K as reported in Møller et al. [44], meaning that only $40 \%$ of the nitrogen substitutes inorganic $\mathrm{N}$. 


\section{Results and discussion}

In this section, disaggregated results are presented as characterized potential impacts, together with comparative results for the five scenarios analysed and the sensitivity analysis. For sake of clarity, Figure 5 only displays the processes with the largest contribution; the remaining processes are grouped under "remaining processes". Detailed contribution analysis is provided in Supporting Information (Figure S6 to figure S8).

\subsection{Impact assessment of the biorefinery system (Scenario 4)}

Figure 4 presents potential environmental impacts for the biorefinery system distributed among the output products of the refinery. It can be seen that the main credits to the system are due to the biodiesel (replacing fossil diesel) and rape meal (substituting for soy meal). This was quite expectable, as these two flows represent the main outputs (both mass and energy) of the biorefinery system. Figure 4 also shows that potential impacts are distributed similarly across the analysed impact categories, the only exception being combustion of lignin that results in savings when considering global warming whereby it represents a burden to the environment in terrestrial eutrophication, mainly due to $\mathrm{NH}_{3}$ and $\mathrm{NO}_{\mathrm{x}}$ from the combustion process.

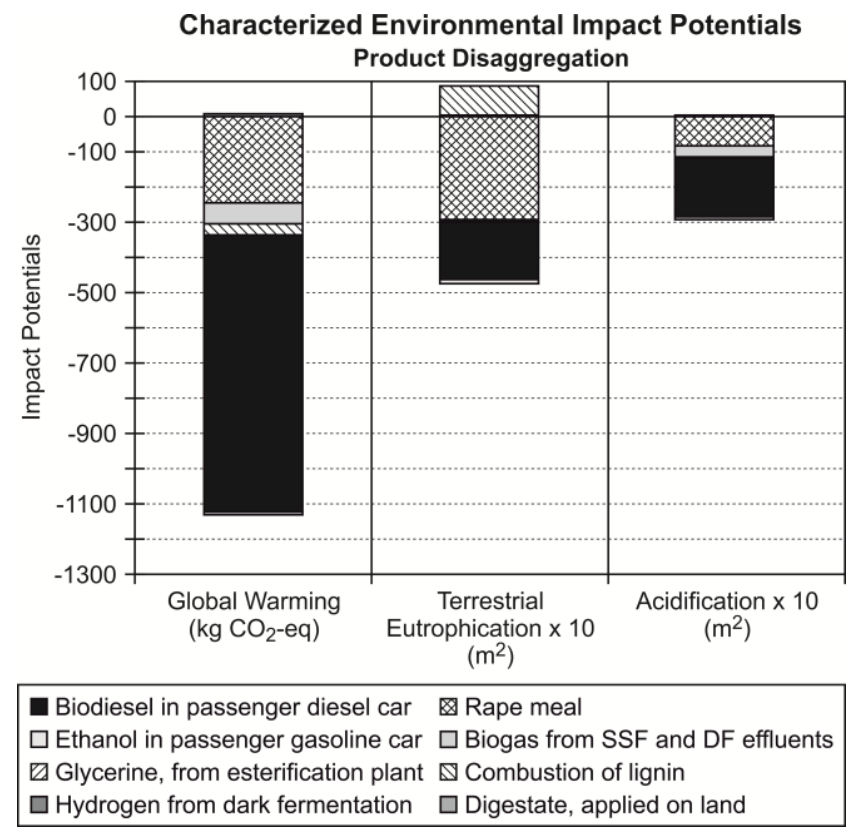

Figure 4 - Distribution of potential environmental impacts (units in brackets) among different outputs of the biorefinery system (Scenario 4) for $1 \mathrm{Mg}$ of rapeseed input. 
Figure 5 presents potential environmental impacts for the biorefinery system disaggregated into sub-processes. It is seen that the substitution of fossil diesel with biodiesel has important benefits for the global warming impact category, representing the major saving. The production of rape meal has also benefits because it results in large savings linked to the avoided production of soy meal in Brazil (both soybean production and provision of land). Two significant burdens are represented by palm oil production in Malaysia - an indirect downstream effect of increased rape meal production - and removal of rapeseed straw from field (on global warming, not displayed in the figure for cut-off reasons), indicating that these processes should not be excluded from the modelling. With regards to Acidification and Terrestrial Eutrophication categories, contributions from sub-processes are distributed similarly to Global Warming, thereby indicating that the latter can be a good indicator for non-toxic categories when evaluating bioenergy systems.

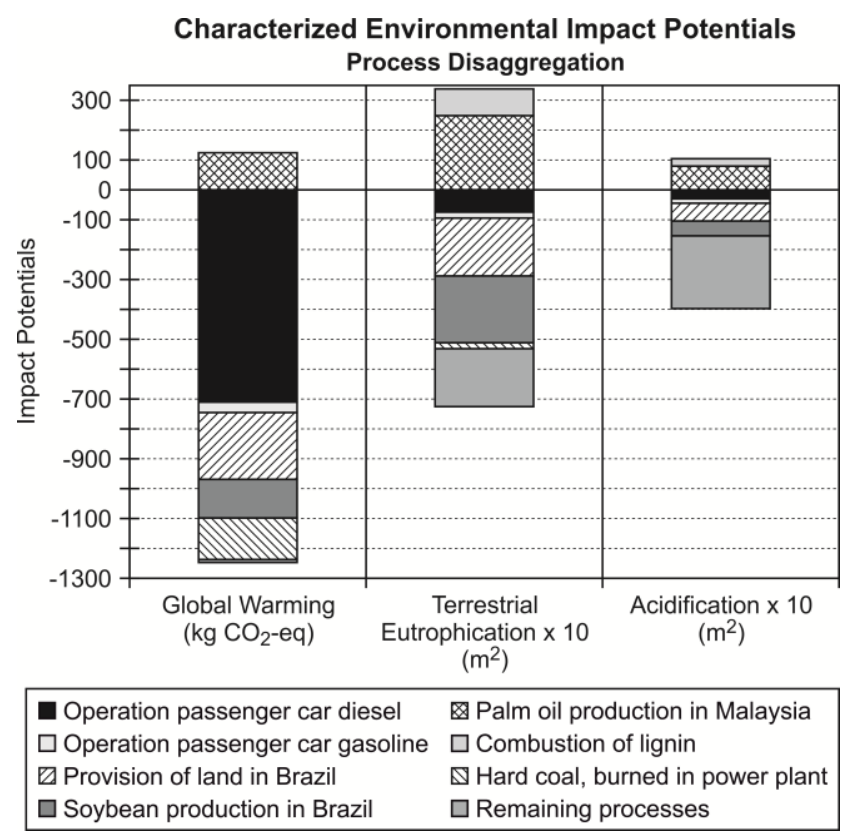

Figure 5 - Contribution of different sub-processes to potential environmental impacts (units in brackets) related to the biorefinery system (Scenario 4) for $1 \mathrm{Mg}$ of rapeseed input. 


\subsection{Comparative results}

Comparative results for the assessed scenarios are presented in Figure 6, presented as normalised potential impacts. As expected, results are negative (i.e. avoided impacts form substituted processes are larger than direct burdens) for all scenarios and all impact categories, meaning that there are overall potential environmental benefits. For all impact categories, the introduction of enzymatic transesterification results in some environmental benefits (compared to traditional process), due to the increased diesel production - the improved rapeoil extraction has a lower meal-to-oil ratio. The decrease input of energy and materials to the transesterification process has a minor effect. However, these findings are very sensitive to the assumptions made and thus the related parameters will be screened in the sensitivity analysis. When looking at Scenarios 3 to 5, it can be seen that the collection and utilization of straw can have environmental benefits. In terms of global warming, Scenarios 3 to 5 show improvements compared to Scenario 2 in the order of 29,9 and $10 \%$ respectively. Relative improvements are a bit smaller for the acidification (10, 12, and 14\% for Scenarios 3, 4, and 5 respectively) and eutrophication $(7,0$, and $2 \%)$. The combustion of straw performs better than the conversion of straw to different biofuels (i.e. ethanol, hydrogen, methane) from a global warming perspective. This result was expectable, as combustion of straw involves fewer conversion processes and thus less energy losses. However, it should be remembered that, with regards to the transportation sector, liquid and gaseous fuels have logistically some advantages (e.g. they are storable and can be used as high-energy-density fuels in aviation and for other specific applications) compared to electricity and heat. From Figure 6 it can also be noted that the use of hydrolysate for the production of hydrogen (Scenario 4) or methane (Scenario 5) leads to similar results, despite different performances of the two processes: the lower conversion efficiency and higher energy consumption of the dark fermentation is compensated by the production of a higher quality fuel (hydrogen). 


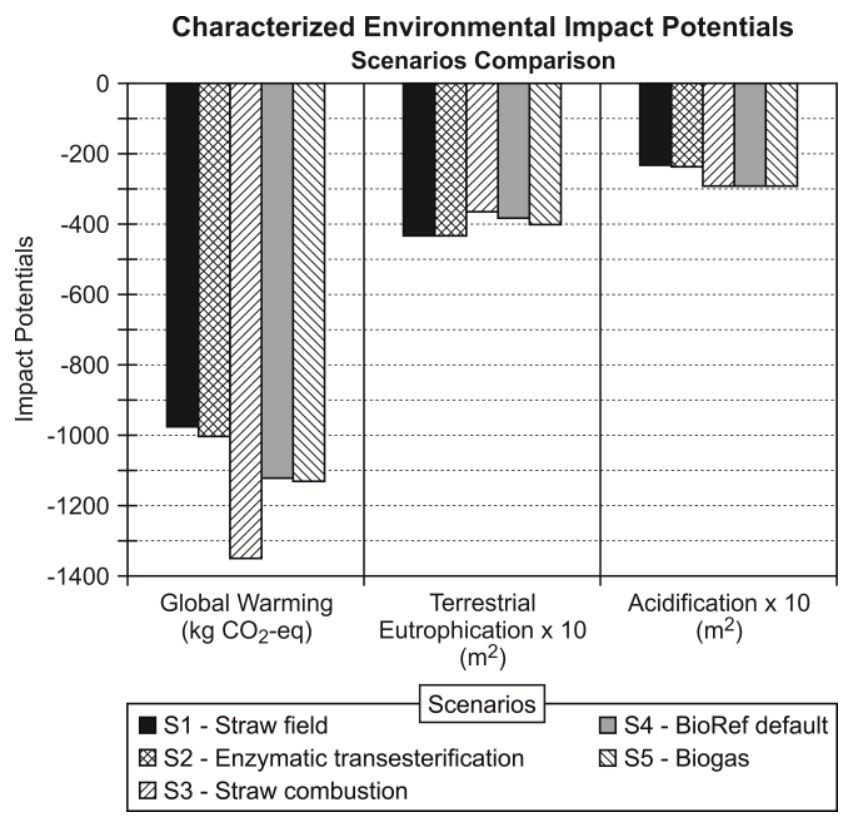

Figure 6 - Potential environmental impacts (units in brackets) for the analysed scenarios for 1 Mg of rapeseed input.

\subsection{Sensitivity analysis}

The robustness of results in relation to different factors was tested by means of uncertainty important analysis [45], which includes an assessment of the relevance of different parameters on the results, a qualitative evaluation of their uncertainty, and a sensitivity test.

A number of parameters were selected. A qualitative evaluation of the uncertainty was carried out as follow:

- Meal-to-oil ratio for Scenario 1 was provided by an existing biodiesel producer. Improved extraction efficiency was assumed to be equal to a start-of-the-art chemical extraction method, since the effects of the enzymatic treatment on the hulls are not known yet. The assumption regarding the meal-to-oil ratio can thus be considered highly uncertain.

- The consumption of electricity during enzymatic transesterification was estimated by means of process simulation [28] and it is thus associated with low uncertainty.

- The consumption of enzymes during enzymatic transesterification was estimated by means of process engineering [28] and it is thus associated with low uncertainty. 
- The straw-to-seed ratio was extrapolated from official statistics for Denmark. However, productivity of future rapeseed species is not easily predictable. The parameter it considered medium uncertain.

- The marginal electricity mix was chosen according the standard and well-agreed LCA approach applied in Denmark. However, future marginal electricity mix is based on modelling and speculations done for the future energy scenarios and it is thus less certain. The chosen mix is thus considered medium uncertain.

- The consumption of enzymes during SSF was assumed to be in the same order as for the enzymatic transesterification process. However, this data is not verifiable as literature is scarce on the subject. The used value is associated with high uncertainty.

The relevance of the selected parameters on the results was determined based on the results presented previously (Figure 4 to 6 ) and are presented in Table 6. The influence of the different parameters on the results was evaluated with a sensitivity test. Selected parameters were varied in the respective scenarios according to Table 6 . The quantitative results of the test are shown graphically in Figure 7 by means of variation intervals. The sensitivity of each parameter was then described with a qualitative indicator: high sensitivity was assigned in case the variation interval was larger than the absolute (numerical) difference between the analysed scenarios or if the variation interval was large relatively to the impact in itself. The qualitative results are reported in Table 7 and show that none of the parameters is critical.

The qualitative results of the sensitivity analysis are shown in Table 7 and they indicate that the most problematic parameters are the straw-to-crop ratio and the chosen marginal electricity mix. Results are also affected to a minor extent by the uncertainty introduced by parameters such as the meal-to-oil ratio and the consumption of enzymes during SSF. Despite the fact that none of the parameters listed in Table 7 seem to heavily affect the conclusions drawn from the results, it is still recommended to carry out further investigations in the future to improve the quality of these parameters. Similarly, the modelling of the marginal technologies and processes is based on assumptions and interpretations of market mechanisms that may need to be checked with changing economy dynamics in the future. 


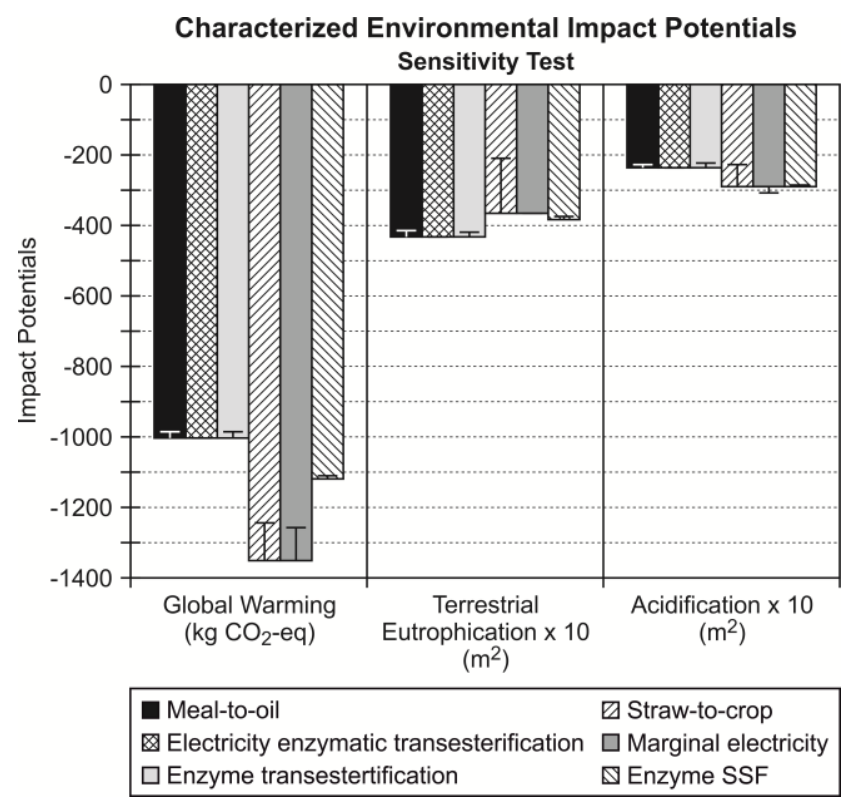

Figure 7 - Results of the sensitivity test (variation intervals) for the selected parameters (details provided in Table 6).

\section{Conclusions}

In the present study we have carried out a technological assessment of a biorefinery concept under development in Denmark for the conversion of rapeseed into different biofuels and valuable products. Results were calculated for three impact categories (global warming, acidification, terrestrial eutrophication) and they show that the introduction of enzymatic transesterification could potentially results in environmental benefits, but mainly for the improved rapeoil extraction procedure than for savings of energy/materials during the esterification process. The utilization of rapeseed straw for energy purposes showed also an improved environmental footprint compared to the $1^{\text {st }}$ generation (traditional) biorefinery system, regardless the conversion option adopted. The production of liquid and gaseous biofuels is not as efficient as combustion for recovering the energy contained in the straw, but has certainly some advantages for the variety of possible products and their nature - liquid fuels have high energy content and can be easily stored or transported. The energy balance showed also that the energy consumption in different processes (i.e. hydrothermal treatment and dark fermentation) employed for conversion of straw is quite relevant and thus from a technological perspective improvements are potentially achievable and needed. Based on the 
assumptions made in the study, the use of enzymes (in enzymatic transesterification and SSF) does not pose a major environmental concern. However, data from full scale facilities using enzymes are needed to confirm the findings. The sensitivity analysis showed that further investigations are also needed to better define output/output ratios in some of the processes (i.e. straw-to-crop and meal-to-oil ratios).

\section{Acknowledgments}

The authors would like to acknowledge the financial support of the Danish Agency for Science, Technology and Innovation under Bio REF. Project No. 2104-06-0004. 


\section{References}

1. EC. Directive 2009/28/EC of the European Parliament and of the Council of 23 April 2009 on the promotion of the use of energy from renewable sources and amending and subsequently repealing Directives 2001/77/EC and 2003/30/EC. Official Journal of the European Union, 140:16-45, June 2009. OJ:L:2009:140:0016:0062:EN:PDF.

2. Al-Riffai P, Dimaranan B, Laborde D (2011) Global trade and environmental impact study of the EU biofuels mandate. International Food Policy Institute (IFPRI), Washington, USA, 2010. Last accessed March 2011 at: http://trade.ec.europa.eu/doclib/html/145954.htm

3. Bendz K (2006) EU-25 Oilseeds and Products Annual 2006. USDA Foreign Agricultural Service, Brussels, 2006. Last accessed March 2011 at: www.fas.usda.gov/gainfiles/200606/146197961.pdf.

4. Thy $\varnothing$ KA, Wenzel H (2007) Life Cycle Assessment of Biogas from Maize silage and from Manure. Institute for Product Development, Technical University of Denmark, 2007. Last accessed March 2011 at: http://www.xergi.com/images/stories/pdf/life_cycle_assessment_report.pdf

5. Cherubini F, Jungmeier G (2010) LCA of a biorefinery concept producing bioethanol, bioenergy, and chemicals from switchgrass. Int J Life Cycle Assess 15:53-66.

6. Halleux H, Lassaux S, Renzoni R, Germain A (2008) Comparative life cycle assessment of two biofuels. Ethanol from sugar beet and rapeseed methyl ester. Int J LCA 13:184-190.

7. Uihlein A, Schebek L (2009) Environmental impacts of a lignocellulose feedstock biorefinery system: an assessment. Biomass Bioenergy 33:793-802.

8. Cherubini F, Ulgiati S (2010) Crop residues as raw materials for biorefinery systems - A LCA case study. Applied Energy 87;47-57.

9. Thamsiriroj T, Murphy JD (2010) Can Rape Seed Biodiesel Meet the European Union Sustainability Criteria for Biofuels? Energy Fuels 24:1720-1730.

10. Hedegaard K, Thy $\varnothing$ KA, Wenzel H (2008) Life cycle assessment of an advanced bioethanol technology in the perspective of constrained biomass availability. Env Sci Technol 42:79927999.

11. Harding KG, Dennis JS, von Blottnitz H, Harrison STL (2006) A life-cycle comparison between inorganic and biological catalysis for the production of biodiesel. J Clean Prod 16:1368-1378.

12. Li L, Du W, Liu D, Wang L, Li Z (2006) Lipase-catalyzed transesterification of rapeseed oils for biodiesel production with a novel organic solvent as the reaction medium. J Molecular Catalysis B: Enzymatic 43:58-62.

13. Fjerbaek L, Christensen KV, Norddahl B (2009) A Review of the Current State of Biodiesel Production Using Enzymatic Transesterification. Biotechnol Bioeng 2009;102:1298-1315.

14. Dong $\mathrm{M}$, Walker TH. Characterization of high-pressure carbon dioxide explosion to enhance oil extraction from canola. J Supercr Fluids 44:193-200.

15. Bellostas N, Sørensen AD, Sørensen JC, Sørensen H (2007) Genetic variation and metabolism of glucosinolates in cruciferous oilseed crops. In: Rapeseed Breeding: Advances in Botanical Research (Ed. Dr. Surinder Gupta) Academic Press/ Elsevier, Dan Diego, Vol. 45.

16. Cornblatt BS, Ye L, Dinkova-Kostova AT, Erb M, Fahey JW, Singh NK, Chen MA, Stierer T, Garrett-Mayer E, Argani P, Davidson NE, Talalay P, Kensler TW, Visvanathan K (2007) 
Preclinical and clinical evaluation of sulforaphane for chemoprevention in the breast. Carcinogenesis 28:1485-1490.

17. Thomsen $\mathrm{MH}$, Thygesen $\mathrm{A}$, Thomsen AB (2008) Hydrothermal treatment of wheat straw at pilot plant scale using a three-step reactor system aiming at high hemicellulose recovery, high cellulose digestibility and low lignin hydrolysis. Biores Technol 99:4221-4228.

18. Petersen $M \varnothing$, Larsen J, Thomsen MH (2009) Optimization of hydrothermal pretreatment of wheat straw for production of bioethanol at low water consumption without addition of chemicals. Biomass Bioenergy 33:834-840.

19. Díaz MJ, Cara C, Ruiz E, Romero I, Moya M, Castro E (2010) Hydrothermal pre-treatment of rapeseed straw. Bioresour Technol 101:2428-2435.

20. Kongjan P, Min B, Angelidaki I (2009) Biohydrogen production from xylose at extreme thermophilic temperatures $(70 \stackrel{\circ}{ })$ ) by mixed culture fermentation. Water Research 43:1414-1424.

21. Kaparaju P, Serrano M, Thomsen AB, Kongjan P, Angelidaki I (2009). Bioethanol, biohydrogen and biogas production from wheat straw in a biorefinery concept. Biores Technol 100:2562-2568.

22. Petersson A, Thomsen $\mathrm{MH}$, Hauggaard-Nielsen $\mathrm{H}$, Thomsen A-B. Potential bioethanol and biogas production using lignocellulosic biomass from winter rye, oilseed rape and faba bean. Biomass Bioenergy 2007;31:812-819.

23. Schmidt JH (2007) Life cycle assessment of rapeseed oil and palm oil. Part 3: Life cycle inventory of rapeseed oil and palm oil. Ph.D. thesis, Department of Development and Planning Aalborg University, Denmark, 2007.

24. Sustoil (2010) Optimisation of primary processing. Deliverable 2.5 from WP2 in "Developing advanced Biorefinery schemes for integration into existing oil production/transesterification plants". Last accessed May 2012 at: http://www.york.ac.uk/res/sustoil/Pages/Deliverable\%202-5.pdf

25. Jeong T-S, Um B-H, Kim J-S, Oh K-K (2010) Optimizing Dilute-Acid Pretreatment of Rapeseed Straw for Extraction of Hemicellulose. App Biochem Biotech 161:22-33.

26. Jungbluth N, Chudacoff M, Dauriat A, Dinkel F, Doka G, Faist Emmenegger M, Gnansounou E, Kljun N, Spielmann M, Stettler C, Sutter J (2007) Life Cycle Inventories of Bioenergy. Final report ecoinvent data v2.0. Volume: 17. Swiss Centre for LCl, ESU. Duebendorf and Uster, $\mathrm{CH}$.

27. Emmelev (2010) Data supplied by Emmelev A/S, Denmark, March 2010.

28. Sotoft LF, Rong B-G, Christensen KV, Norddahl B (2010) Process simulation and economical evaluation of enzymatic biodiesel production plant. Biores Technol 101:5266-5274.

29. Weber M (2008) Futtermittel aus Raps - was sagen die Inhaltsstoffe?, UFOP-Information Winterrapsaussaat 2008;6-7. Last accessed March 2011 at: http://www.ufop.de/downloads/Ufop_Information_Winter_08.pdf

30. Nemecek T, Kägi T (2007) Life cycle inventories of Swiss and European agricultural production systems, Final report ecoinvent V2.0 No. 15a. Dübendorf and Zurich (Switzerland): Agroscope Reckenholz-Taenikon Research Station ART, Swiss Centre for Life Cycle Inventories. 
31. Lu X, Zhang Y, Angelidaki I (2009) Optimization of H2SO4-catalyzed hydrothermal pretreatment of rapeseed straw for bioconversion to ethanol: Focusing on pretreatment at high solids content. Biores Technol 100:3048-3053.

32. Cencic O, Rechberger H (2008). Material Flow Anaylsis with Software STAN. J Env Eng Manag 18:3-7.

33. Pré (2008) SimaPro 7.1 PRé Consultants B.V. Plotterweg 12, 3821 AD Amersfoort • The Netherlands, www.pre.nl

34. Hauschild M, Potting J (2005). Spatial differentiation in Life Cycle impact assessment - The EDIP2003 methodology. Environmental news No. 80 2005, Danish Ministry of the Environment, Copenhagen, Denmark.

35. Statistics Denmark. Accessed April 2011 from: www.statistikbanken.dk.

36. Edwards R, Larivé J-F, Mahieu V, Rouveirolles P (2007) Well-to-Wheels analysis of future automotive fuels and powertrains in the European context. WELL-TO-TANK Report. Version 2c. Joint Research Center, Ispra, Italy.

37. Astrup T, Møller J, Fruergaard T (2009) Incineration and co-combustion of waste: accounting of greenhouse gases and global warming contributions. Waste Manag Res 27:789-799.

38. Fruergaard T, Ekvall T, Astrup, T (2009) Energy use and recovery in waste management and implications for accounting of greenhouse gases and global warming contributions. Waste Manag Res 27:724-737.

39. Fruergaard T, Christensen TH, Astrup T (2010) Energy recovery from waste incineration: Assessing the importance of district heating networks. Waste Manag 30:1264-1272.

40. Fruergaard T, Astrup, T (2011) Optimal utilization of waste-to-energy in an LCA perspective. Waste Manag 31:575-582.

41. Schmidt JH, Weidema BP (2008) Shift in the Marginal Supply of Vegetable Oil. Int J LCA 13:235-239.

42. Norouzi A, Peyvast G, Olfati J (2008) Oilseed rape straw for cultivation of oyster mushroom. Mj Int J Sci Technol 2:502-507.

43. Sander B (1997) Properties of Danish biofuels and the requirements for power production. Biomass Bioenergy 12:177-183.

44. Møller, J, Boldrin, A, Christensen, TH (2009) Anaerobic digestion and digestate use: accounting of greenhouse gases and global warming contribution Waste Manag Res 27:813824.

45. Björklund AE (2002) Survey of approaches to improve reliability in LCA. Int J Life Cycle Assess 7:64-72.

46. BIOBIB database. University of Technology Vienna. Last accessed March 2011 at : http://www.vt.tuwien.ac.at/biobib/biobib.html

47. Sheng C, Azevedo JLT (2005) Estimating the higher heating value of biomass fuels from basic analysis data. Biom Bioen 28:499-507.

48. Raavendran K, Ganesh A (1996) Heating value of biomass and biomass pyrolysis products. Fuel 75:1715-1720.

49. Hovelius, K., Hansson, P-A (1999) Energy- and exergy analysis of rape seed oil methyl ester (RME) production under Swedish conditions. Biomass Bioenergy 17, 279-290.

50. Bentsen NS, Felby C, Ipsen KH (2006) Energy balance of 2nd generation bioethanol production in Denmark. Royal Veterinary and Agricultural University, Danish Centre for 
Forest, Landscape and Planning and Elsam Engineering A/S: Copenhagen, Denmark. Last access April 2011

at: http://www.tekno.dk/pdf/projekter/p09_2gbio/ClausFelby/p09_2gbio\%20Bentsen\%20et\%2 Oal\%20(2006).pdf

51. Manish S, Banerjee R (2008) Comparison of biohydrogen production processes. Int J Hydr Ener 33:279-286

52. El-Shafey EI, Gameiro MLF, Correia PFM, de Carvalho JMR (2004) Dewatering of Brewer's Spent Grain Using a Membrane Filter Press: A Pilot Plant Study. Sep Sc Tech 39:3237-3261.

53. Doka G (2009) Life Cycle Inventories of Waste Treatment Services. Ecoinvent report No. 13. Swiss Centre for Life Cycle Inventories, Dübendorf, Switzerland.

54.Gabrielle B, Gagnaire N. (2008) Life-cycle assessment of straw use in bio-ethanol production: a case study based on biophysical modelling. Biomass Bioenergy 32:431-41

55. Jensen E.B, Jørgensen, K, Haldrup, C, Nielsen, K.A, Christensen, B, Wegge, M, Serup, T, Udesen, F, Høy, J.J (2005) Budgetkalkuler 2006, for de enkelte produktionsgrene, Kalenderårene 2005 og 2006 (English: Budget estimates 2006, for single production lines, Calendar years 2005 and 2006). Dansk Landbrugsrådgivning, Landscentret, Aarhus, Danmark.

56. Soon, Y.K, Arshad, M.A (2002) Comparison of the decomposition and N and P mineralization of canola, pea and wheat residues. Biol Fertil Soils 36:10-17.

57. Martínez-Blanco, J, Lazcano, C, Boldrin, A, Muñoz, P, Rieradevall, J, Moller, J, Antón, A, Christensen, TH (2012) Assessing the environmental benefits of compost use-on-land through an LCA perspective: a review. Submitted to Agronomy for Sustainable Development.

58. Pelkmans, L., Lenares, G., Bruynix, J., \& Scheepers, K. (2010) Overview report of emission measurements within BIOSES. Science Policy Office, Boeretang, Belgium 2010.

59. Malça, J., Freire, F. (2011) Life-cycle studies of biodiesel in Europe: A review addressing the variability of results and modeling issues. Renew Sust Energy Rev 15:338-51.

60. Chalmers J, Archer G. Development of a sustainability reporting scheme for biofuels: A UK case study. Ener Pol 39:5682-5689.

61. Reinhard, J, Zah, R. (2009) Global environmental consequences of increased biodiesel consumption in Switzerland: consequential life cycle assessment. J Clean Prod 17:S46-S56.

62. Huo, H, Wang, M, Bloyd, C, Putsche, V. (2009) Life-cycle assessment of energy use and greenhouse gas emissions of soybean-derived biodiesel and renewable fuels. Env Sc Tech 43:750-756.

63. Börjesson, P, Tufvesson, LM. (2011) Agricultural crop-based biofuels - resource efficiency and environmental performance including direct land use changes. J Clean Prod 19:108120.

64. Scifinder database. Accessible at: http://www.cas.org/products/scifinder.

65. IPCC (2003) Good practice guidance for land use, land-use change and forestry. Intergovernmental Panel on Climate Change, Hayama. Last accessed 20-11-2012 at: http://www.ipcc-nggip.iges.or.jp/public/gpglulucf/gpglulucf.html

66. Novozymes (2010) Data supplied by Novozymes A/S, Denmark, March 2010. 
Table 1 - Alternatives for downstream processes (system expansion) relative to different outputs from the biorefinery.

\begin{tabular}{|c|c|c|c|}
\hline Output & Use & Purpose & Substituted process \\
\hline RME & Diesel blend & Vehicles’ fuel & Production of diesel from petroleum \\
\hline \multirow{4}{*}{ Glycerine } & Upgrade to pure glycerine & Use in industrial processes & $\begin{array}{l}\text { Industrial production of synthetic } \\
\text { (pharmaceutical) glycerine }\end{array}$ \\
\hline & Combustion in industrial boilers & Energy production & Energy production based on natural gas \\
\hline & Anaerobic digestion & Energy production & Energy production based on coal \\
\hline & Raw material in chemical industry & Production of chemicals & Petroleum derivates \\
\hline \multirow{2}{*}{ Glucosinolate } & Raw material in agrochemical industry & Production of plants' protection agents & Production of chemical pesticides \\
\hline & Raw material in pharmaceutical industry & Production of health care compounds & Production of anti-carcinogenic compounds \\
\hline \multirow{2}{*}{ Rape meal } & Fodder & Feeding of animals & Production of soybean meal \\
\hline & Fodder & Feeding of animals & Production of spring barley meal \\
\hline Bioethanol & Gasoline blend & Vehicles’ fuel & Production of diesel from petroleum \\
\hline \multirow{2}{*}{ Biohydrogen } & Raw material in chemical industry & Production of chemicals & Industrial production of hydrogen \\
\hline & Use of hydrogen in car fuel cells & Production of electromechanical energy & Production of gasoline from petroleum \\
\hline Lignine & Combustion in biomass plant & Energy production & Energy production based on coal \\
\hline Biogas & Combustion in gas engine (at plant) & Energy production & Energy production based on coal \\
\hline Digestate & Use on agricultural land & Fertilizer & Production of mineral fertilizer \\
\hline Straw & Combustion in biomass plant & Energy production & Energy production based on coal \\
\hline
\end{tabular}


Table 2 - Energy consumptions, energy losses and energy intensities of individual sub-processes of the biorefinery system.

\begin{tabular}{|c|c|c|c|c|c|c|}
\hline \multirow[b]{2}{*}{ Operation } & \multicolumn{4}{|c|}{ Energy consumption } & \multirow{2}{*}{$\begin{array}{c}\text { Energy losses } \\
\mathbf{k J ~ M J}^{-1}{ }_{\text {input }}\end{array}$} & \multirow{2}{*}{$\begin{array}{c}\text { Energy intensity* } \\
\mathbf{k J ~ M J}^{-1} \mathbf{~}_{\text {input }}\end{array}$} \\
\hline & Unit & Electricity & Heat & Source/COMMENT & & \\
\hline Overhead (admin., etc.) & $\mathrm{MJ} \mathrm{Mg}^{-1}$ rapeoil & 4 & 2 & {$[23]$} & & 0.25 \\
\hline Pressing + cake treatment & $\mathrm{MJ} \mathrm{Mg}^{-1}$ seed & 158.4 & 468 & {$[26]$} & 41 & 60 \\
\hline Enzymatic transesterification & $\mathrm{MJ} \mathrm{Mg}^{-1}$ rapeoil & 30.2 & 136.5 & {$[26]^{* *}$} & 18.1 & 120 \\
\hline Supercritical fluid extraction & $\mathrm{MJ} \mathrm{Mg}^{-1}$ rapecake & n.a. & n.a. & - & n.a. & n.a. \\
\hline Hydrothermal treatment & $\mathrm{MJ} \mathrm{GJ}^{-1}$ straw & & 87.8 & [49] & 166 & 104 \\
\hline Dark fermentation & $\mathrm{MJ} \mathrm{kg}^{-1} \mathrm{H}_{2}$ & 20.2 & - & {$[50]$} & 166 & 143 \\
\hline SSF & $\mathrm{MJ} \mathrm{Mg}^{-1} \mathrm{TS}_{\text {input }}$ & 65.5 & - & [44] & 117 & 42 \\
\hline Filter press & $\mathrm{MJ} \mathrm{Mg}^{-1} \mathrm{TS}_{\text {input }}$ & 40.8 & - & [51] & 16 & 17 \\
\hline Anaerobic digestion & $\mathrm{MJ} \mathrm{m}^{-3}$ biogas & 0.54 & - & {$[25] * * *$} & 147 & 70 \\
\hline Water supply & $\mathrm{MJ} \mathrm{m}^{-3}$ water & 0.58 & - & EDIP database & - & - \\
\hline Wastewater treatment & $\mathrm{MJ} \mathrm{m}^{-3}$ wastewater & 0.78 & - & [52] & - & - \\
\hline
\end{tabular}

* Expressed as primary energy

** Values in this study are assumed 30\% lower

*** assumed as an agricultural AD 
Table 3 - Primary energy (MJ) used for the production of electricity, heat, methanol, $\mathrm{H}_{2} \mathrm{SO}_{4}$ and enzymes.

\begin{tabular}{lccc} 
& \multicolumn{1}{c}{ Unit } & Value & Source/comment \\
\hline Coal based electricity & $\mathrm{MJ} \mathrm{MJ}^{-1}$ electricity & 5.95 & EDIP, exergy allocation, DK \\
Coal based heat & $\mathrm{MJ} \mathrm{MJ}^{-1}$ heat & 1.05 & EDIP, exergy allocation, DK \\
Methanol & $\mathrm{MJ} \mathrm{kg}^{-1}$ methanol & 30.2 & {$[25]$} \\
$\mathrm{H}_{2} \mathrm{SO}_{4}$ & $\mathrm{MJ} \mathrm{kg}^{-1} \mathrm{H}_{2} \mathrm{SO}_{4}$ & 3.8 & {$[25]$} \\
Enzymes & $\mathrm{MJ} \mathrm{kg}^{-1}$ enzyme & $63-723$ & {$[66]$} \\
\hline
\end{tabular}


Table 4 - Important parameters and input/output data for the assessed scenarios.

\begin{tabular}{|c|c|c|c|c|c|c|c|c|}
\hline \multirow[b]{2}{*}{ Process } & \multirow[b]{2}{*}{ Parameter } & \multirow[b]{2}{*}{ Unit } & \multicolumn{5}{|c|}{ Scenario } & \multirow[b]{2}{*}{ Source } \\
\hline & & & S1 & $\mathrm{S} 2$ & S3 & S4 & S5 & \\
\hline Harvesting & Straw-to-crop ratio & & 0.9 & 0.9 & 0.9 & 0.9 & 0.9 & [55] \\
\hline Oil extraction & Meal-to-oil ratio & & 1.5 & 1.38 & 1.38 & 1.38 & 1.38 & [23] [24] \\
\hline Straw collection & Straw harvested & \% straw gen. & - & - & 65 & 65 & 65 & [30] \\
\hline Process & Input & Unit & S1 & S2 & S3 & S4 & S5 & \\
\hline \multirow[t]{2}{*}{ Overhead } & Electricity & $\mathrm{MJ} \mathrm{Mg}^{-1}$ oil & 4 & 4 & 4 & 4 & 4 & {$[23]$} \\
\hline & Heat cons. & $\mathrm{MJ} \mathrm{Mg}^{-1}$ oil & 2 & 2 & 2 & 2 & 2 & [23] \\
\hline \multirow[t]{4}{*}{ Oil extraction } & Electricity & $\mathrm{kWh} \mathrm{Mg}^{-1}$ seed & 44 & 44 & 44 & 44 & 44 & [27] \\
\hline & Gas & $\mathrm{m}^{3} \mathrm{Mg}^{-1}$ seed & 12 & 12 & 12 & 12 & 12 & [27] \\
\hline & Hexane & $\mathrm{kg} \mathrm{Mg}^{-1}$ seed & 1.1 & - & - & - & - & [26] \\
\hline & $\mathrm{H}_{3} \mathrm{PO}_{4}$ & $\mathrm{~kg} \mathrm{Mg}^{-1}$ seed & 0.3 & - & - & - & - & [26] \\
\hline \multirow[t]{8}{*}{ Transesterification } & Electricity & $\mathrm{MJ} \mathrm{Mg}^{-1}$ oil & 43.2 & 30.2 & 30.2 & 30.2 & 30.2 & {$[28]$} \\
\hline & Heat & $\mathrm{MJ} \mathrm{Mg}^{-1}$ oil & 195 & 136.5 & 136.5 & 136.5 & 136.5 & [28] \\
\hline & $\mathrm{NaOH}$ catalyser & $\mathrm{kg} \mathrm{Mg}^{-1}$ oil & 10 & - & - & - & - & [13] \\
\hline & Methanol & $\mathrm{kg} \mathrm{Mg}^{-1}$ oil & 110 & 110 & 110 & 110 & 110 & [4] [6] [26] \\
\hline & $\mathrm{H}_{3} \mathrm{PO}_{4}$ & $\mathrm{~kg} \mathrm{Mg}^{-1}$ oil & 4.5 & - & - & - & - & [13] \\
\hline & Water & $\mathrm{kg} \mathrm{Mg}^{-1}$ oil & 26.6 & 13.3 & 13.3 & 13.3 & 13.3 & [26] \\
\hline & Enzymes (Novozym 435) & $\mathrm{kg} \mathrm{Mg}^{-1}$ oil & - & 0.5 & 0.5 & 0.5 & 0.5 & {$[12][13][28]$} \\
\hline & Enzymes (Lipozyme TL) & $\mathrm{kg} \mathrm{Mg}^{-1}$ oil & - & 1.5 & 1.5 & 1.5 & 1.5 & [12] [13] [28] \\
\hline Glucosinolate extr. & Electricity & $\mathrm{MJ} \mathrm{Mg}^{-1}$ rapecake & - & - & - & n.a. & n.a. & \\
\hline Hydrothermal & Heat & MJ GJ ${ }^{-1}$ straw & - & - & - & 87.8 & 87.8 & calc. \\
\hline \multirow[t]{2}{*}{ treatment } & Water & $\mathrm{Mg} \mathrm{Mg}_{\mathrm{dw}}^{-1}$ straw & - & - & - & 4 & 4 & calc. \\
\hline & $\mathrm{H}_{2} \mathrm{SO}_{4}$ & $\mathrm{~kg} \mathrm{Mg}_{\mathrm{dw}}^{-1}$ straw & - & - & - & 50 & 50 & calc. \\
\hline \multirow[t]{3}{*}{ SSF } & Electricity & $\mathrm{MJ} \mathrm{Mg}^{-1} \mathrm{TS}_{\text {input }}$ & - & - & - & 65.5 & 65.5 & [26] \\
\hline & Enzymes (Celluclast) & kg Mg-1 cellulose & - & - & - & 5.5 & 5.5 & {$[12][13][28]$} \\
\hline & Enzymes (Novozym 188) & kg Mg-1 cellulose & - & - & - & 2.5 & 2.5 & {$[12][13][28]$} \\
\hline Dark fermentation & Electricity & $\mathrm{MJ} \mathrm{kg}^{-1} \mathrm{H}_{2}$ & - & - & - & 20.2 & - & [51] \\
\hline Filter press & Electricity & $\mathrm{MJ} \mathrm{Mg}^{-1} \mathrm{TS}_{\text {input }}$ & - & - & - & 40.8 & 40.8 & calc. \\
\hline $\begin{array}{l}\text { Anaerobic } \\
\text { digestion }\end{array}$ & Electricity & $\mathrm{MJ} \mathrm{m}^{-3}$ biogas & - & - & - & 0.54 & 0.54 & [26] \\
\hline Process & Output & Unit & S1 & $\mathrm{S} 2$ & S3 & $\mathrm{S} 4$ & S5 & \\
\hline \multirow[t]{2}{*}{ Transesterification } & RME & $\mathrm{kg} \mathrm{Mg}^{-1}$ oil & 980 & 980 & 980 & 980 & 980 & calc. \\
\hline & Glycerine & $\mathrm{kg} \mathrm{Mg}^{-1}$ oil & 110 & 110 & 110 & 110 & 110 & calc. \\
\hline Glucosinolate Extr. & Glucosinolate & $\mathrm{kg} \mathrm{Mg}^{-1}$ rapecake & - & - & - & 0.67 & 0.67 & calc. \\
\hline \multirow[t]{3}{*}{ Straw combustion } & Electricity & GJ $\mathrm{Mg}_{\mathrm{dw}}^{-1}$ straw & - & - & 4.7 & - & - & calc. \\
\hline & Heat & GJ $\mathrm{Mg}^{-1}{ }_{\mathrm{dw}}$ straw & - & - & 13.3 & - & - & calc. \\
\hline & Ash & $\mathrm{kg} \mathrm{Mg}_{\mathrm{dw}}^{-1}$ straw & - & - & 42.5 & - & - & calc. \\
\hline \multirow[t]{2}{*}{ SSF } & Bioethanol & $\mathrm{kg} \mathrm{Mg}^{-1}{ }_{\mathrm{dw}}$ straw & - & - & - & 108 & 108 & calc. \\
\hline & Lignin & $\mathrm{kg} \mathrm{Mg}_{\mathrm{dw}}^{-1}$ straw & - & - & - & 171 & 171 & calc. \\
\hline Dark fermentation & Biohydrogen & $\mathrm{kg} \mathrm{Mg}_{\mathrm{dw}}^{-1}$ straw & - & - & - & 3.4 & - & calc. \\
\hline Anaerobic & Methane & $\mathrm{kg} \mathrm{Mg}_{\mathrm{dw}}^{-1}$ straw & - & - & - & 88 & 93 & calc. \\
\hline digestion & Digestate & $\mathrm{kg} \mathrm{Mg}^{-1}{ }_{\mathrm{dw}}$ straw & - & - & - & 304 & 319 & calc. \\
\hline
\end{tabular}


Table 5 - Alternatives for downstream processes (system expansion) relative to different outputs from the biorefinery.

\begin{tabular}{|c|c|c|c|}
\hline Output & Use & Purpose & Substituted process \\
\hline RME & Diesel blend & Vehicles’ fuel & Production of diesel from petroleum \\
\hline \multirow{4}{*}{ Glycerine } & Upgrade to pure glycerine & Use in industrial processes & $\begin{array}{l}\text { Industrial production of synthetic } \\
\text { (pharmaceutical) glycerine }\end{array}$ \\
\hline & Combustion in industrial boilers & Energy production & Energy production based on natural gas \\
\hline & Anaerobic digestion & Energy production & Energy production based on coal \\
\hline & Raw material in chemical industry & Production of chemicals & Petroleum derivates \\
\hline \multirow{2}{*}{ Glucosinolate } & Raw material in agrochemical industry & Production of plants' protection agents & Production of chemical pesticides \\
\hline & Raw material in pharmaceutical industry & Production of health care compounds & Production of anti-carcinogenic compounds \\
\hline \multirow{2}{*}{ Rape meal } & Fodder & Feeding of animals & Production of soybean meal \\
\hline & Fodder & Feeding of animals & Production of spring barley meal \\
\hline Bioethanol & Gasoline blend & Vehicles’ fuel & Production of diesel from petroleum \\
\hline \multirow{2}{*}{ Biohydrogen } & Raw material in chemical industry & Production of chemicals & Industrial production of hydrogen \\
\hline & Use of hydrogen in car fuel cells & Production of electromechanical energy & Production of gasoline from petroleum \\
\hline Lignine & Combustion in biomass plant & Energy production & Energy production based on coal \\
\hline Biogas & Combustion in gas engine (at plant) & Energy production & Energy production based on coal \\
\hline Digestate & Use on agricultural land & Fertilizer & Production of mineral fertilizer \\
\hline Straw & Combustion in biomass plant & Energy production & Energy production based on coal \\
\hline
\end{tabular}


Table 6 - Sensitivity test for different parameters and scenarios.

\begin{tabular}{|c|c|c|c|c|c|c|}
\hline Test name & Tested scenario & Parameter changed & Change & From & \multicolumn{2}{|c|}{ To } \\
\hline Meal-to-oil & Scenario 2 & Meal-to-oil ratio & $+5 \%$ & 1.38 & - & 1.45 \\
\hline Electricity enzymatic & Scenario 2 & Electricity use in & $\pm 20 \%$ & 30.2 & 24.2 & 36.2 \\
\hline $\begin{array}{l}\text { transesterification } \\
\text { Enzyme }\end{array}$ & Scenario 2 & $\begin{array}{l}\text { enzymatic transester. } \\
\text { Enzyme consumption }\end{array}$ & $+300 \%$ & $\begin{array}{l}\mathrm{MJ} \mathrm{Mg}^{-1} \text { oil } \\
2\end{array}$ & $\mathrm{MJ} \mathrm{Mg}^{-1}$ oil & $\begin{array}{c}\mathrm{MJ} \mathrm{Mg}^{-1} \text { oil } \\
8\end{array}$ \\
\hline transesterification & & during transester. & & $\mathrm{kg} \mathrm{Mg}^{-1}$ oil & & $\mathrm{kg} \mathrm{Mg}^{-1}$ oil \\
\hline Straw-to-crop & Scenario 3 & Straw-to-crop ratio & $+33 \%$ & 0.9 & - & 1.2 \\
\hline Marginal electricity & Scenario 3 & Marginal electricity mix & & Coal & \multicolumn{2}{|c|}{ Danish mix } \\
\hline Enzyme SSF & Scenario 4 & $\begin{array}{l}\text { Enzyme consumption } \\
\text { during SSF }\end{array}$ & $+300 \%$ & $\begin{array}{c}8 \\
\mathrm{~kg} \mathrm{Mg}^{-1} \\
\text { cellulose }\end{array}$ & - & $\begin{array}{c}32 \\
\mathrm{~kg} \mathrm{Mg}^{-1} \\
\text { cellulose }\end{array}$ \\
\hline
\end{tabular}


Table 7 - Qualitative results of the uncertainty importance analysis.

\begin{tabular}{lccc} 
Parameter & Uncertainty & Relevance on the results & Sensitivity \\
\hline Meal-to-oil & High & High & Low \\
Electricity requirements & Low & Low & Low \\
Enzyme transesterification & Low & Medium & Low \\
Straw-to-crop & Medium & High & Medium \\
Electricity mix & Medium & High & Medium \\
Enzyme SSF & High & Medium & Low \\
\hline
\end{tabular}

